\title{
COVID-19, the firestone in 21st century: a review on coronavirus disease and its clinical perspectives
}

\author{
Chenmala Karthika ${ }^{1} \cdot$ R Swathy Krishna ${ }^{2} \cdot$ Md. Habibur Rahman ${ }^{3}$ (I) Rokeya Akter $^{4} \cdot$ Deepak Kaushik $^{5}$
}

Received: 18 May 2021 / Accepted: 17 September 2021 / Published online: 1 October 2021

(C) The Author(s), under exclusive licence to Springer-Verlag GmbH Germany, part of Springer Nature 2021

\begin{abstract}
The severe acute respiratory syndrome coronavirus 2 (SARS-CoV-2) outbreak began in late 2019 in Wuhan, China, and have since spread globally. Deep sequencing analysis identified the disease within a few weeks, and on February 11, the World Health Organization (WHO) named it "COVID-19 caused by SARS-CoV-2." SARS-CoV-2 was declared a global pandemic by the WHO in March 2020. Coronavirus disease has become a global challenge for researchers and health care workers, affecting over 174 million people and causing over 3 million deaths. Because of the widespread nature, extensive measures are being taken to reduce person-to-person contact, and special precautions are being taken to prevent the transmission of this infection to vulnerable populations such as geriatrics, pediatrics, and health care professionals. We summarized the genesis of COVID-19 spread, its pathology, clinical perspectives, and the use of natural ingredients as a possible cure for COVID-19 in this review. This article has highlighted information about current vaccines approved for emergency use as well as those in various stages of clinical trials. Vaccine availability around the world is a promising development in the fight against the SARS-CoV-2 virus. We conducted a narrative review to present the current state and research on this situation, specific diagnosis, clinical manifestation, emergency approaches, herbal-based remedies, and COVID vaccines.
\end{abstract}

Keywords COVID-19 $\cdot$ Severe acute respiratory syndrome $\cdot$ Pathology $\cdot$ Therapeutic strategy $\cdot$ Natural remedies $\cdot$ COVID vaccines $\cdot$ Clinical trials

$\overline{\text { Chenmala Karthika and Rokeya Akter contributed equally to this work. }}$

Responsible Editor: Lotfi Aleya

Md. Habibur Rahman

pharmacisthabib@gmail.com

1 Department of Pharmaceutics, JSS College of Pharmacy, JSS Academy of Higher Education \& Research, Ooty, Nilgiris, Tamil Nadu, India

2 Department of Pharmacology, JSS College of Pharmacy, JSS Academy of Higher Education \& Research, Ooty, Nilgiris, Tamil Nadu, India

3 Department of Pharmacy, Southeast University, Banani, Dhaka 1213, Bangladesh

4 Department of Pharmacy, Jagannath University, Sadarghat, Dhaka 1100, Bangladesh

5 Department of Pharmaceutical Sciences, Maharshi Dayanand University, Rohtak 124001, India

\section{Introduction}

The novel coronavirus disease 2019 is caused by severe coronavirus (COVID-19). SARS-CoV-2 (acute respiratory syndrome coronavirus) was discovered and reported in December 2019 in Wuhan, China, and has since spread to become a global pandemic. The SARS-CoV-2 virus has a long incubation period of up to 33 days (in some studies, an incubation period of more than 14 days was used) and a fast transmission rate that is faster than that of other coronaviruses, such as SARS-CoV and middle east respiratory syndrome (MERS)-CoV. Asymptomatic carriers can spread the virus as well. The majority of SARS-CoV-2 patients experience mild-to-moderate symptoms; however, approximately $15 \%$ develop severe pneumonia, and approximately 5\% develop acute respiratory distress syndrome (ARDS), septic shock, multiple organ failure, and even death. As a result of the aforementioned characteristics, COVID-19 had spread to more than 200 countries by June 1, 2021, resulting in more than 170,000,000 confirmed cases and 3,782,490 confirmed deaths. As a result of the pandemic, which has made humans 
more vulnerable to microbial pathogens and revealed gaps in our therapeutic arsenal, scientists are working at an unprecedented pace to understand the disease and find a cure. At the moment, two major courses are thought to be driving COVID19 pathogenesis. SARS-CoV-2 identification, fusion, entry, and replication, also known as the replication cycle, are primarily driven by viral proteins in the early stages of infection progression. A massive inflammatory/immune response to SARS-CoV-2 that causes tissue damage drives the late stage of infection progression (Bogoch et al. 2020). As a result, both virus proteins and host factors are required for COVID-19 pathogenesis, making them promising anti-viral therapy targets.

Coronavirus $(\mathrm{CoV})$ was first isolated in 1987 and is thought to be a primordial variant found in pangolins or bats. Coronaviruses cause bronchitis in birds, decimating the poultry population. In 1960, the human strand of coronaviruses $(\mathrm{HCoV})$ was isolated from the noses of common cold patients. OC43 and 229E were the two main strands of the HCoV obtained. The term coronavirus refers to the crown-like projections on surfaces of coronaviruses. In Latin, the term "corona" means "halo" or "crown." Coronaviruses are a type of virus that commonly affects the nose, upper throat, and sinuses (Rahman et al. 2021).

The centers for disease control and prevention (CDCP) begins to see the emergence of a new coronavirus known as SARS-CoV-2 in 2019. The first case of human transmission was discovered in Wuhan, China. Coronaviruses are linked to viruses that can cause disease in humans and animals. SARSCoV-2 is one of seven types of coronaviruses, which include the common ones that cause severe diseases such as SARS and MERS. The other types are primarily viruses that cause colds and do not cause serious infections. SARS virus strain known as SARS-CoV is a coronavirus association. The new strain of $\mathrm{CoV}$ is known as SARS-CoV-2, and it is the cause of coronavirus disease (COVID-19). Other members of this virus family include SARS-CoV and MERS-CoV. COVID-19 was identified sequentially as SARS-CoV in approximately $79 \%$ of cases and MERS-CoV in approximately $50 \%$ of cases. Furthermore, homology modeling revealed that the receptorbinding domain of SARS-CoV and COVID-19 is the angiotensin-converting enzyme 2 (ACE2) receptor in humans, causing infection (Bogoch et al. 2020; Lu et al. 2020a; Zhao et al. 2020). COVID-19 is a respiratory tract infection that can affect both the upper and lower respiratory tracts. Their infection ranges from mild to fatal in humans and is spread primarily through person-to-person contact. The effect of coronavirus on the respiratory tract is given in Fig. 1.

The new coronavirus strain has rapidly spread throughout the world. COVID-19 was declared a pandemic by the World Health Organization on March 11, 2020 (Du Toit 2020; Calisher et al. 2020). A pandemic occurs when an infection to which people are not immune spreads across larger geographic areas. Geriatrics, those with cardiovascular or respiratory disorders and diabetic patients, are at the greatest risk. According to various reports, nosocomial infections are more likely in the case of COVID-19 (Corman et al. 2020; Wang et al. 2020a, b, c; Nishiura et al. 2020; Rahman et al. 2020).

\section{Structure of COVID-19}

The structure of the COVID-19 (Fehr AR 2015) mainly consists of a nucleocapsid protein, RNA, membrane protein, envelope protein, hemagglutinin-esterase dimer, and a spike protein, as represented in Fig. 2.

\section{Nucleocapsid (N) protein}

The nucleocapsid (N) protein possesses in vitro affinity and is highly phosphorylated, playing an important role in translation and transcription. $\mathrm{N}$ protein binds to the genome of the virus in a string type confirmation. This protein triggers the viral genome to replicate-transcriptase complex (RTC) and finally results in packing the encapsulated genome into viral particles.

\section{Membrane (M) protein}

Membrane (M) protein is a widely expressed structural protein and is the most abundant protein. It exhibits its action by binding to the nucleocapsid and by promoting membrane curvature. It is also called the central organizer for the coronavirus assembly.

\section{Envelope (E) protein}

Envelope (E) protein is found within the virus in a very small quantity and is mainly a transmembrane protein and activates the ion channels. It facilitates the protein assembly and release of the virus, but this protein is not involved in the viral replication process.

\section{Hemagglutinin-esterase (HE) dimer protein}

Hemagglutinin-esterase (HE) dimer protein binds to the sialic acids which are present on the surface of glycoproteins, enables its action via entering into the spike protein-mediated cells, and spreads through the mucosa.

\section{Spike (S) protein}

Spike (S) protein is located on the surface of the virus, facilitating the entry of SARS-CoV-2 into the human cells. It is highly glycosylated and employs an $\mathrm{N}$-terminal signaling pathway to achieve its access to the endoplasmic reticulum 


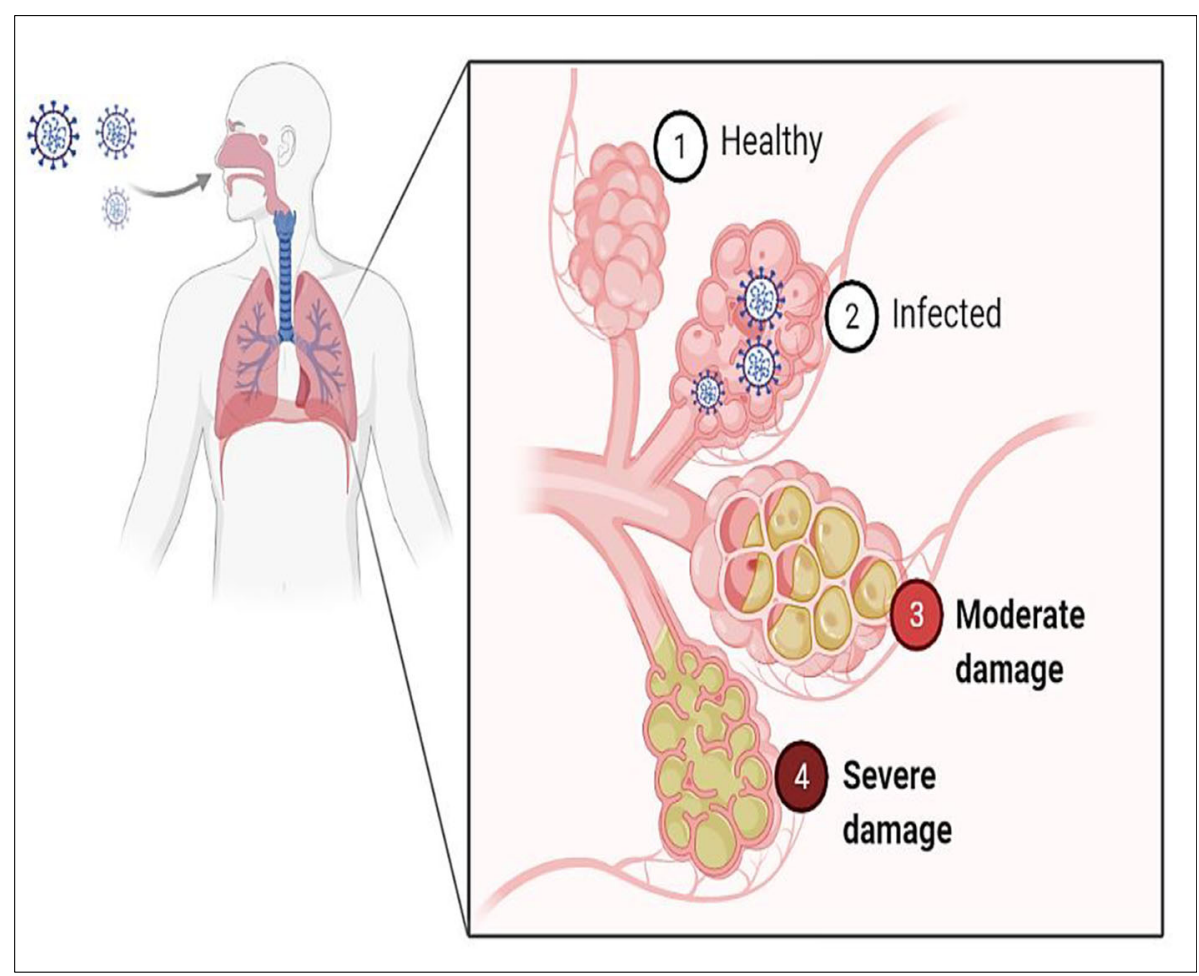

Moderate damage: Accumulating fluid, reduced gas exchange

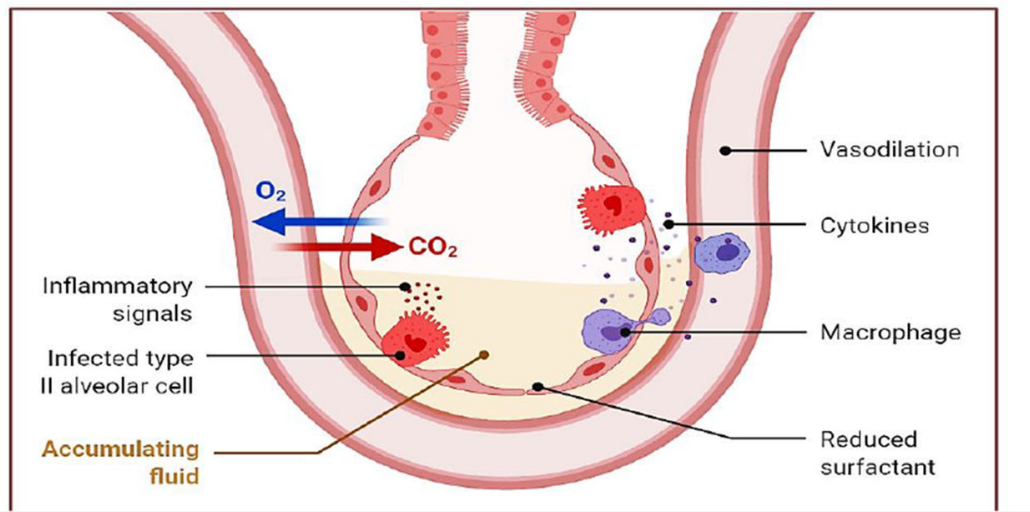

Severe damage: Build up of protein-rich fluid, very limited gas exchange

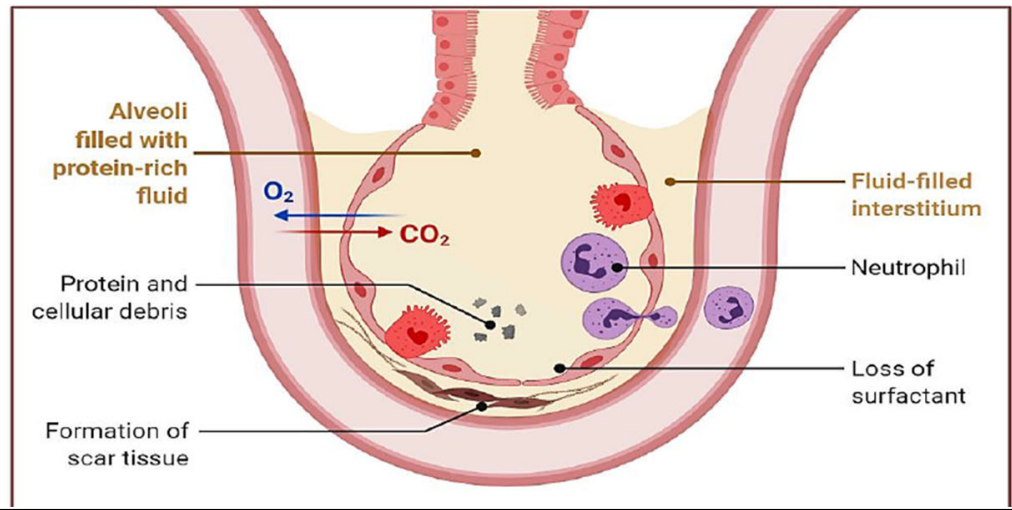

Fig. 1 Effect of SARS-CoV-2 on the respiratory tract 
Fig. 2 Structure of SARS-CoV-2

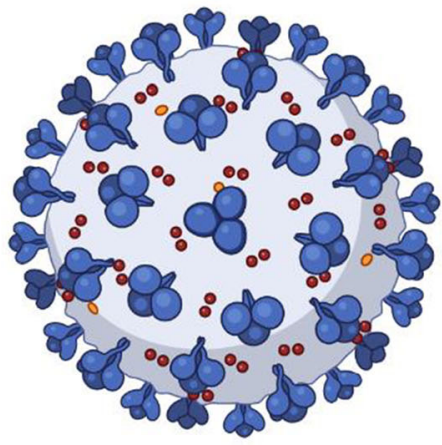

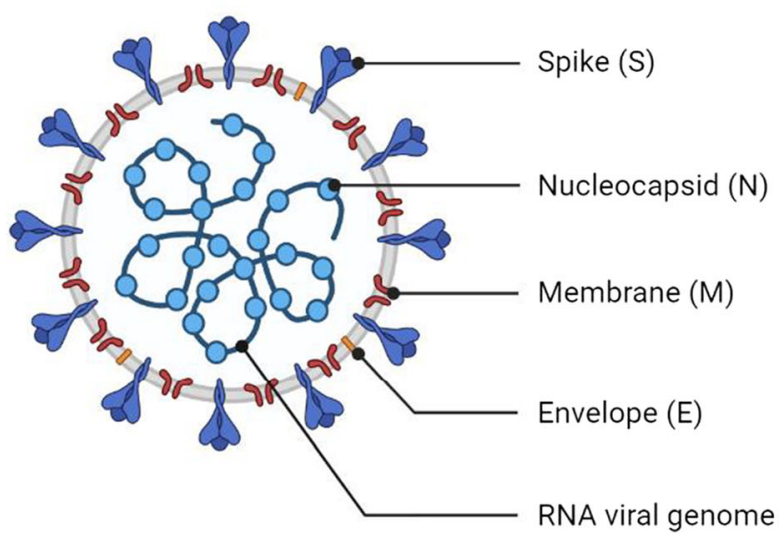

and furthermost attaching to the host receptors. For the majority of coronaviruses, S-proteins are cleaved into two different polypeptide domains, $\mathrm{N}$-terminal $\mathrm{S} 1$ subunit and $\mathrm{C}$-terminal $\mathrm{S} 2$ subunit. The $\mathrm{S} 1$ contains receptor-binding domain (RBD) for binding onto host cell receptors while the S2 subunit mediates the membrane fusion.

\section{Transmission of SARS-CoV-2}

COVID-19 is thought to be of zoonotic origin based on the spread of the disease from the Wuhan animal market. Efforts are being made to locate the reservoir from which it emerged and spread throughout the human population. The initial report identified two snake species as possible origins, but no proper evidence was reported aside from the possibility of mammals and birds. COVID-19's genomic similarities with the bat sequence accounted for $88 \%$ of the total. Evidence suggests that person-to-person contact is the most common cause of this infection's spread (Holshue et al. 2020).

When COVID-19 patients cough or breath out, the virus is expelled in the form of tiny droplets, which can enter the nose or mouth of people who are not infected, resulting in the onset of the disease. When symptoms are at their worst, this infection is extremely contagious. The virus can settle in droplets on nearby objects or surfaces. When a person comes into contact with the virus through their eyes, nose, or mouth, they are likely to become infected (Thompson 2020). It should be noted that the COVID-19 is progressing and that the researchers are still open-ended. In the case of coronavirus spread, there are additional modes of transmission.

The initial binding of host cell receptors and subsequent fusion with the cell membrane is the primary mechanism involved in viral infection. It has been discovered that the primary target of this virus is the epithelial cells of the lungs. As a result, it has been determined that the transmission of SARS$\mathrm{CoV}$ to humans, as well as its action, is linked to the binding of the virus spikes receptor-binding domain and the ACE2 cellular receptors. Because the SARS-CoV and COVID-19 receptor-binding domains are similar, the binding is most likely via ACE2 receptors (Wang et al. 2020a, b, c, Nishiura et al. 2020).

\section{Symptoms and clinical significance}

The symptoms of COVID-19 appear after an incubation period of approximately 5.2 days (Thompson 2020). The validity period ranges from 6 to 41 days, with an average of 14 days, from the onset of virus action to death. The patient's immunity is the most important factor in determining death. The most common COVID-19 symptoms are fever, persistent cough, shortness of breath, diarrhea, lymphopenia, and hemoptysis. Symptoms should appear 2-14 days after being exposed to the virus. On day 9 of the illness, a mild symptom of progression and presentation pneumonia is observed. Clinical approach related to chest CT scan is evaluated for the effect of pneumonia, and other features like acute respiratory distress syndrome (Rothan and Byrareddy 2020; Assiri et al. 2013a, b; Lee et al. 2003), the incidence of grant-glass opacities (some cases both sides of the lungs were observed) (Assiriet al. 2013), and acute cardiac injury. The main reason for the therapeutic strategy's failure is a decrease in immune response and inflammation, as well as opacities in the pulmonary progression.

The parallels between the earlier beta-coronavirus and COVID-19 are striking. Although symptoms such as dry cough, fever, bilateral ground-glass opacities on CT scan, and dyspnea are shared by both (Lee et al. 2003), the unique clinical characteristics of the COVID-19 such as sneezing, rhinorrhea, and sore throat distinguish them. Diarrhea is a common gastrointestinal symptom in COVID-19 patients as well as MERS-CoV or SARS-CoV patients. As a result, the patient should have urine and fecal tests performed to determine the next route of transmission (Brubaker et al. 2013; Phan et al. 2020).

\section{Pathophysiology and clinical aspect}

Coronaviruses are positive-strand RNA viruses with the largest-known RNA genome (30-32 kb) and a 5-cap and 3- 
poly-A-tail. While the transcription process works through randomized controlled trials (RCT) complex, which is the replication-transcription complex organized in the vesicles, the synthesis of polyproteins $1 \mathrm{a} / 1 \mathrm{ab}$ in the host cell is taken into account. Transcription is terminated at the transcription regulatory sequence, which is located between the open reading frames (ORFs), which serve as a template for sub-genomic mRNA production. ORF1a and ORF1b guide the production of the polypeptides ppla and $\mathrm{pp} 1 \mathrm{~b}$ which are further processed by the main protease. Aside from ORFs, structural proteins such as nucleocapsid, membrane, spike, and envelope proteins are encoded. The structural proteins, the envelope, play a role in the pathogenicity of the virus by preventing virus assembly and release. In some cases, the viral infection causes exaggerated immune responses in the host or even a "cytokine storm," which can result in extensive tissue damage. Interleukin-6 (IL-6), which is produced by leukocytes and acts on a variety of cells and tissues, is the star of this cytokine storm. IL-6's primary function is to promote B lymphocyte differentiation, but it also has proinflammatory properties. The SARS-CoV-2 virus enters the lungs via the respiratory tract and begins targeting organs that express angiotensin-converting enzyme 2, such as the heart, lungs, renal, and gastrointestinal systems (Fehr and Perlman 2015).

The majority of COVID-19 cases are associated with a patient profile that includes an elevated body temperature of $39^{\circ} \mathrm{C}$ for 5 days, as well as coughing and breathing difficulties (Lu et al. 2020b). A real-time polymeric chain reaction is used to analyze the sputum of a COVID-19 infected patient. The laboratory results show $2.91 \times 10^{9}$ cells/L leukocytes, of which $70 \%$ was neutrophils, resembling leucopenia. A C-protein concentration of $16.16 \mathrm{mg} / \mathrm{L}$ was also reported (Wan et al. 2020). D-dimer and erythrocyte sedimentation rates are also elevated. Elevated levels of interleukin-1 receptor antagonist (IL-1RA), interleukin-1 (IL-1), interleukin-10 (IL-10), interleukin-9 (IL9), interleukin-8 (IL8), interleukin-7 (IL7), granulocyte-colony-stimulating factor (GCSF), granulocyte-macrophage colony-stimulating factor (GMCSF), interferon-inducible protein-10 (IP10), interferon (IFN), macrophage inflammatory proteins (MIP1), MIP1B, tumor necrosis factor (TNF), plateletderived growth factor subunit $\mathrm{B}$ (PDGFB), and vascular endothelial growth factor A (VEGFA) have also been reported (Brubaker et al. 2013; Lu et al. 2020b; Wu et al. 2020). The abnormal range of pro-inflammatory cytokines can lead to disease severity in some cases. The COVID19 clinical spectrum ranges from symptomatic to asymptomatic, with respiratory failure that may necessitate ventilation support. In COVID-19-infected patients, a chest CT scan reveals opacification with or without abnormalities.

\section{Risk criteria}

A few factors can influence the risk of virus exposure, while others may play a role in the progression of severe illness. According to the World Health Organization, the likelihood of becoming infected with COVID-19 is low in most cases (Jaimes et al. 2020). The spread is most visible in people who have frequent contact with patients and health care workers. Older adults are at a much higher risk of contracting the severe infection caused by SARS-CoV-2, as are people with certain medical conditions such as asthma, chronic kidney disease, cystic fibrosis, and diabetes.

\section{Prevention}

Recommending effective approaches to halt the spread of SARS-CoV-2 is now a global challenge (Hui et al. 2020). Anti-viral vaccination primarily inhibits viral action, but developing a vaccine or any treatment modalities for a newly developed strain of virus takes time (Brubaker et al. 2013). The formulation against these viral strands should be developed safely and effectively. The best way to prevent this virus from spreading is to avoid close contact with the infected person and to practice good personal hygiene (Cui et al. 2019; Zhu et al. 2020; Ngandu et al. 2015).

The CDC recommends washing hands with water and soap for 20 seconds each time after public exposure. In the absence of soap, hand sanitizers containing at least $60 \%$ alcohol are recommended and avoid touching your face with your hands before washing them (Wang et al. 2020a, b, c).

Public bodies and the government are developing preventive measures to break the chain of transmission of SARS$\mathrm{CoV}-2$ and to educate the public about the disease. The high mortality rate in the population is primarily due to patients' low immunity.

In addition, to the evolution, adaptation, and spread of the disease, the major challenges that should be effectively monitored are epidemiological changes and mutation. It has also been reported that the disease has spread to pet animals such as dogs. In this pandemic situation, there are still several unanswered questions (Bassetti et al. 2020). Personal protective equipment (PPE) is a method of infection prevention and control that is commonly used by passengers on flights and health care professionals as a preventive measure against becoming infected. The PPE acts as a face shield and is worn by healthcare professionals or other individuals to prevent infection.

Is there a cure for COVID-19? According to the CDC, there is no specific medication used to treat COVID-19 at this time; instead, patients are given supportive care. The primary reason for the isolation of patients suffering from this disorder is the transmission of this disease from person to person. This 
approach is primarily used to prevent the virus from spreading to the community and to reduce the severity of the disorder globally (Toots et al. 2019, Jin et al. 2020). The current treatment strategy that doctors are using to reduce viral infection is a combination of HIV protease inhibition and broad-spectrum anti-viral drugs such as nucleotide analogs. The anti-viral drug is administered in the course of oral twice-daily administration of oseltamivir (75 mg), lopinavir (500 mg), and intravenous administration of ganciclovir $(0.25 \mathrm{~g})$ for 3-14 days (Ngandu et al. 2015, Lu et al. 2020b). According to research published in 2019, chloroquine and broad-spectrum anti-viral drugs are effective against $\mathrm{CoV}$ infection. These medical strategies were found to be safe and are being considered for the treatment of COVID-19 infection. Until and unless an invention for the therapy of COVID-19 is made, RNA synthase inhibitors, peptide (EK1), neuraminidase inhibitors, and ritonavir/lopinavir were included in the patients' medication history.

It is important to note that more researchers needed the drug discovery and drug development process to create a medication for the safe and effective treatment of COVID-19. There is a need for pharmacological evaluation of the developed drug and for that animal model to be replicated with the disease as of the human epidermis for evaluating the pre-and post-exposure prophylaxis parameters against COVID-19 (Jaimes et al. 2020; Toots et al. 2019; Rothan and Byrareddy 2020; Shah et al. 2021). This SARS-CoV-2 outbreak caused a devastating economic, social, political, and global health problem. However, several vaccines are being developed, and some are undergoing clinical trials. These may include

- nucleic acid vaccine: these are mRNA-based vaccines including Moderna;

- viral vector vaccines including AstraZeneca and sputnik $\mathrm{V}$;

- inactivated virus vaccine including Sinovac vaccine; and

- antigen-based vaccine including EpiVac corona.

Use of natural products for COVID-19 Natural remedies have been used for the treatment and cure of viral infections all over the world since ancient times. They are safe and effective treatments for viral infections, and research on natural ingredients that can be used for the management and treatment of various disorders is ongoing (Lalani and Poh 2020). Such natural products have a favorable efficacy and a tolerable level of toxicity (Huang et al. 2020). Figure 3 depicts some examples of possible natural remedies for the management of COVID-19, as well as possible formulation approaches.

\section{Use of flavonoids as a natural remedy}

Flavonoids are a type of phenolic natural product that is widely used in both traditional and modern medicine to treat various viral infections. Flavonoids inhibit coronavirus replication in silico, and the main protease is required for virus replication. A docking study revealed that naringenin can effectively bind to the protease by forming a hydrogen bond with the amino acids of the main protease, indicating that naringenin can inhibit the SARS-CoV-2 protease (Khaerunnisa et al. 2020). Flavonoids have been studied extensively in a wide variety of RNA and DNA viruses (Zakaryan et al. 2017; Dou et al. 2011). In silico studies also demonstrated quercetin's inhibitory action against SARSCoV-2, owing to its high affinity for binding to the main protease. Another study found that flavonoids like kaempferol, luteolin-7-glucoside, catechin, naringenin, catechin, quercetin, and epigallocatechin were effective against SARS-CoV-2. Rutin was also thought to be effective against SARS-CoV-2. Flavonoids' mechanisms of action are as follows:

- block the binding and influx of the virus into the cells,

- inhibit the process of viral replication, and

- polyprotein or translation process to inhibit the attack of the virus to various cells.

Other inhibitory activity of the flavonoids includes

- flavonoids that act on the specific extracellular region of the virus-like the viral protein visible on capsid;

- prevention of the viral host attachment and the entry of the virus; some flavonoids can even change the structure of the virus;

- inhibition of the replication at an early stage;

- inhibition of transcription and translation;

- last stage mutation blocking; and

- modulating the immune system and reduce viral load.

The following Table 1 includes a summary of some bioactive compounds with their mechanisms (Pastor et al. 2021).

\section{Role of vaccines against COVID-19}

Millions of people have already contracted the virus, and around 2 million deaths have been reported. The researchers are working round the clock for the development of effective vaccines (Hossain et al. 2020; Sharma et al. 2021). The vaccine passes through several stages before the manufacturer can get approval. In the USA, Food and Drug Administration (FDA) approves and the CDC works to ensure the safety of the public. Vaccines mimic the infectious agent which may be a virus, bacteria, or any other microorganism causing the disease to which our immune system rapidly responds. Earlier, the weak form of the infectious agent was used which allows the immune system to work based on "memory" so as when 


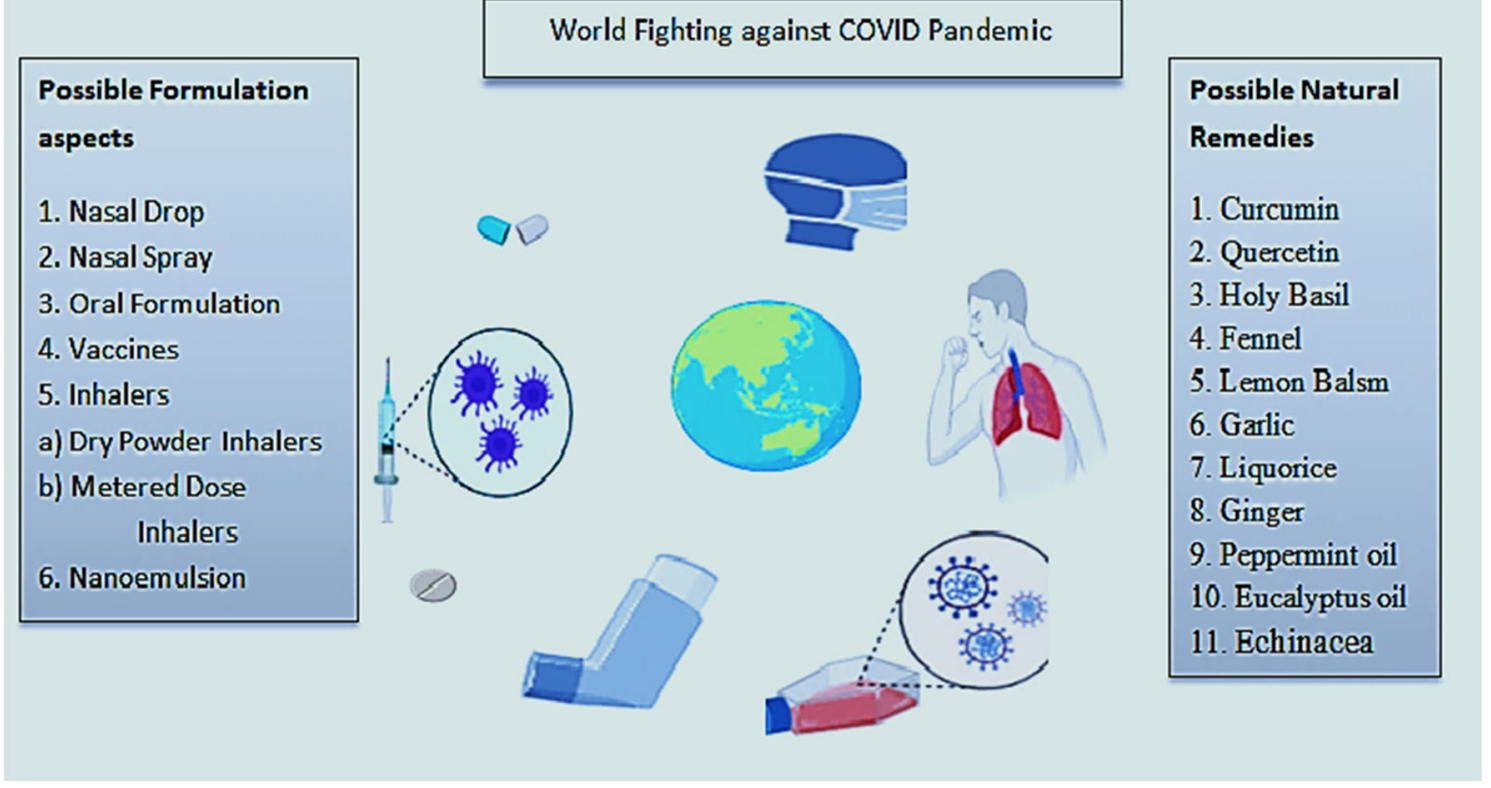

Fig. 3 Possible formulation aspects and natural remedies for COVID-19

the actual infection happens, the immune system quickly recognizes it and prepares antibodies (What You Need to Know about COVID-19 Vaccines $\mid$ UNICEF, n.d.). Now, other different types of vaccine approaches, including mRNA vaccines, inactivated vaccines, protein adjuvant vaccines, or live vaccines, were also developed; firstly, three vaccines were authorized by the FDA also (UPDATED Comparing COVID-19 Vaccines: Timelines, Types and Prices | BioSpace, n.d.). Data from several phase III vaccine efficacy trials were reported at the end of 2020, paving the way for these vaccines to be approved and rolled out. The following organizations have reported vaccine efficacy data. PfizerBioNTech, Moderna, AstraZeneca-University of Oxford,
Johnson \& Johnson, Gamaleya, Sinovac Biotech, Sinopharm, Novavax, and Bharat Biotech are among the companies involved. Except for the Novavax vaccine, each of these vaccines had been approved for rollout to adults and, in some cases, adolescents as of June 14, 2021, through a variety of approval processes based on region and regulatory agency.

\section{Pfizer-BioNTech}

It was the first vaccine to be approved for emergency use by the FDA, as it was mentioned to be $95 \%$ effective for the prevention of symptomatic disease for people older than 12

Table 1 Summary of some bioactive compounds with their mechanisms

\begin{tabular}{|c|c|c|c|}
\hline Bioactive & Food & In vitro properties & Mechanism \\
\hline Curcumin & Curcuma longa (turmeric) & $\begin{array}{l}\text { Anti-oxidant,anti-fibrosis, } \\
\text { and } \\
\text { anti-inflammation }\end{array}$ & $\begin{array}{l}\text { Good binding affinity toward the main protease; } \\
\text { inhibit aminopeptidase; } \\
\text { reduction of AT1 and AT2 receptors; } \\
\text { decrease macrophage population }\end{array}$ \\
\hline Kaempferol & Cabbage, spinach, dill, beans & $\begin{array}{l}\text { Anti-cancer, } \\
\text { anti-oxidant, and } \\
\text { anti-inflammatory }\end{array}$ & $\begin{array}{l}\text { The affinity of binding with ACE- } 2 \text {; } \\
\text { inhibit ion channel receptor and regulation of T-cell re- } \\
\text { ceptor }\end{array}$ \\
\hline Quercetin & Onion, tea, grape, Hypericum perforatum & $\begin{array}{l}\text { Anti-oxidant, } \\
\text { anti-viral, and } \\
\text { anti-inflammatory }\end{array}$ & Affinity against ACE-2 and protease \\
\hline Apigenin & $\begin{array}{l}\text { Celery, oranges, parsley, Matricaria } \\
\text { chamomilla }\end{array}$ & $\begin{array}{l}\text { Anti-hyperglycemic, } \\
\text { anti-oxidant, } \\
\text { anti-viral, and } \\
\text { anti-inflammatory }\end{array}$ & $\begin{array}{l}\text { Reduction of COX-2; } \\
\text { decreasing interleukin- } 6 \text { level; } \\
\text { target ACE-2 }\end{array}$ \\
\hline
\end{tabular}

$A T 1$, angiotensin II type 1; $A T 2$, angiotensin II type 2; $A C E-2$, angiotensin-converting enzyme 2; $C O X$-2, cyclooxygenase-2 
years old. For this, two shots were recommended which were 21 days apart. It is a type of mRNA vaccine which delivers genetic code from SARS-CoV-2 to the host cells giving instructions for making spike protein copies. The spike protein does the work of infecting and penetrating the host cells which also helps in stimulating the immune response and also produces antibodies. The reported side effects include headache, pain, chills, headache, and swelling at the site of injection.

\section{Moderna}

This vaccine was the second one to get emergency approval from the Food and Drug Administration in December 2020. It is also an mRNA-based vaccine with high efficacy in preventing symptomatic disease. It is recommended for adults 18 years and older. This vaccine also requires two shots 28 days apart. One of the advantages offered by this vaccine is that it can be kept in storage for much longer up to 30 days with normal refrigeration, but the limitation of this vaccine was that it showed less effectiveness up to $86 \%$ in people who are 65 years and older. The side effects include pain, headache, chills, and swelling at the injection site.

\section{Johnson \& Johnson}

It is a type of viral vector vaccine and got its approval in February 2021 by the Food and Drug Administration for emergency approval. It can also be administered to 18 years or older adults. As it is a type of carrier vaccine, it uses an adenovirus that carries genetic code to cells by producing spike proteins that will train the immune system of the body. In comparison to Moderna and Pfizer, it has the advantage in that it is easier to store and requires a single shot. But in July, FDA has made a warning that the Johnson \& Johnson vaccine in rare cases can lead to neurological disorders.

\section{Oxford-AstraZeneca}

This vaccine is based on the principle of carrier vaccine but offers the advantage of lower cost and can be stored in normal refrigeration conditions for a period of up to 6 months. Some countries suspended its use as it showed the development of blood clots within 2 weeks after the vaccination is done. It was recommended for 18 years or older adults with two doses, 4 to 12 weeks apart. On March 25, 2021, AstraZeneca proved the efficacy against the symptomatic COVID-19 to be $76 \%$ and $100 \%$ in severe cases while $85 \%$ efficacy in people who are aged 65 years or older.

\section{Novavax}

This is the type of protein adjuvant vaccine that has been found to be effective against COVID-19 and also against the mutations. It is a type of vaccine that has spike protein itself but is being formulated as a nanoformulation. It is also recommended for adults more than 18 years of age with two doses, 3 weeks apart. The common side effects include tenderness, headache, and pain at the site of injection.

\section{Gamaleya Sputnik V}

It is a viral vector, given in two doses; the second dose is given 21 days apart from the first dose. It shows with $92 \%$ of efficacy and is recommended to the age group above 18. From the trial's start date to the present, no variants have been identified originating from the trial locations (June 2021)

\section{Bharath Biotech - Covaxin}

It is a viral vector, given to subjects above the age of 18 . Given in two doses, the second dose is given 28 days apart from the first dose. The phase III trial began on November 16, 2020, and is still ongoing in India; variants discovered include B.1.617.2 and B.1.617.1.

\section{Sinovac Biotech - CoronaVac}

It is an inactive virus, given in two doses; the second dose is given 14-28 days after the first dose. Multiple studies are conducted in various countries such as Brazil (50.7\%), Indonesia (65\%), Chile (56.5\%), Brazil (78\%), and Turkey (91\%). Given to the subjects above the age of 18 is $51 \%$ efficacy against symptomatic SARS-CoV-2 infection, 100\% efficacy against severe disease, and $100 \%$ efficacy against hospitalization beginning 14 days after the second dose.

\section{Sinopharm - BBIBP-CorV}

It is an inactive form of the virus. Given in two doses, the second dose is given 21 days after the first dose. It is given to the age group above 18. During this time, no variants originating from trial sites have been identified (June 2021).

\section{Novavax}

It is a protein subunit; the second dose is given 21 days after the first dose. It is given to the age group above 18 , and $100 \%$ efficacies have been shown.

\section{VECTOR - EpiVacCorona}

It is a protein subunit, given in 2 doses; the second dose is given 21-28 days after the first dose. During this time, no variants originating in the trial locations have been identified (June 2021). 
Clinical trial of vaccines against SARS-COV-2 There are several vaccines that are in different phases of clinical trials globally. Table 2 provides a summary of these clinical trials.

\section{Post-COVID complications}

Since the outbreak of this pandemic, research has focused on the rapid diagnosis and development of new therapies for the effective treatment of COVID-19, as it is not only a respiratory disease, but it has also been discovered that high levels of some endogenous substances are being produced in response to the virus' inflammation (Andrade et al. 2021). A GuillainBarre syndrome characterized by polyneuropathies is one of the immune system complications. It was reported in clinical trials of pediatric, adolescent, and adult patients. Other reports show that cases of COVID-19-associated arthritis condition and 456 rheumatic patients over the age of 60 were reported (Pablos et al. 2020). According to reports, an autoinflammatory disease known as Kawasaki disease was observed, which primarily affects children under the age of five years and causes acute inflammation in caliber vessels, macrophage activation, and increased cardiac involvement. The complications associated with the hematological system result in a direct effect of SARS-CoV-2 linked hyper inflammation, which produces some endogenous substances promoting vascular hemostasis and blood coagulation, which is directly affected by the release of pro-inflammatory and procoagulant cytokines. The SARS-CoV-2 entry mechanism is mediated by the Hace2-R receptor, which is found in the lungs, intestinal smooth muscles, heart, kidneys, and liver. Binding to the hACE2-R causes a decrease in receptor density on vascular tissue, which is associated with the negative regulation of $\mathrm{h}$ ACE2-R activity, followed by angiotensin II accumulation, which causes vasoconstriction, pro-inflammatory, and profibrotic effects. Respiratory failure, pulmonary embolism, thromboembolism, pneumonia, and post-viral fibrosis are some of the other pulmonary complications (Moniruzzaman et al. 2020).

The pathophysiological findings in COVID-19 patients indicate a high risk of myocarditis, myocardial injury, and heart failure. Myocardial injury is detected in $25 \%$ of hospitalized patients with the COVID-19 condition, which is associated with a risk of death. High levels of cytokines and mediators such as TNF- $\alpha$, IL- 6 , and nitric oxide may cause myocardial depression. Digestive system complications and clinical manifestations such as diarrhea, abdominal pain, anorexia, gastrointestinal hemorrhage, constipation, and acid reflux were also reported. According to various reports and surveys, $20 \%$ of COVID patients developed mental health issues such as anxiety, depression, or dementia within 3 months of diagnosis, according to a doctor in the USA (Van Hees et al. 2020). Depression is a condition or disorder that primarily interferes with an individual's normal life. In this era, especially as the coronavirus pandemic is prolonging and harming individuals, the causes of depression and its related suicidal death are becoming more prevalent. Not only in this era but also one out of every ten people suffers from depression at some point in their lives as a result of low self-esteem(Woods and Scott 2016). There is a need for a safe and effective health care regimen that can aid positive feedback on people's mental health by increasing the country's economy through increased participation in the work field.

Menthol or peppermint oil has already been shown to be effective in the treatment of depression, even in severe health conditions such as myocardial infarction (Törnblom and Drossman 2018). We are moving forward with a hypothesis that includes a combination of peppermint oil, an essential oil, and a proven anti-depressant herbal extract of Hypericum perforatum (Setorki 2020; Du Toit 2020) in omega 3-fatty acid-based nano-droplets to be evaporated in a vaporized form inside the room or offices to keep people happy and improve their social lives.

The above-mentioned strategic plan is innovative in the following ways.

1. The combination of the strategy of anti-depressants such as menthol, Hypericum perforatum, and omega-3 fatty acid provides a synergistic effect, which is a novel concept working behind.

2. The conversion of these combinations into nano-droplets and converting into vapors using the active machine similar to the mosquito coil machine.

3. Using the nano-droplets as a room freshener and antidepressant safely and effectively.

4. The lipid pro-drug approach is used which can increase the bioavailability of the drug into the brain by targeting the olfactory receptors and helps in crossing blood-brain barriers.

5. The individual drugs or compounds such as menthol, Hypericum perforatum, and omega-3 fatty acid are proven anti-depressant drugs, but this combination strategy is unique and novel.

The combination of menthol, Hypericum perforatum, and omega-3 fatty acid is novel and can be used safely and effectively. This combination can be used as a mind relaxant and also as an anti-depressant, as a medicament.

The in vitro and in vivo results should be supportive such as nasal toxicity, histopathological studies, and bioavailability. The target of the drug is to reach the brain and the ability to cross blood-brain barrier. The main approach needed is the assurance of quality, safety, and efficacy before producing to the market.

The combination approach used with the aid of natural ingredients is easily accessed, safe, and economical with 
Table 2 Summary of clinical trials being conducted on different COVID-19 vaccines in individuals with different age groups

\begin{tabular}{|c|c|c|c|c|c|c|}
\hline Title & Status & Interventions & Age & Phases & Locations & NCT number \\
\hline $\begin{array}{l}\text { Use of BCG vaccine as a preventive } \\
\text { measure for COVID-19 in health care } \\
\text { workers }\end{array}$ & $\mathrm{R}$ & Live & $\begin{array}{l}18 \text { years and } \\
\text { older }\end{array}$ & Phase 2 & Brazil & NCT04659941 \\
\hline $\begin{array}{l}\text { BCG vaccine in reducing morbidity and } \\
\text { mortality in elderly individuals in } \\
\text { COVID-19 hotspots }\end{array}$ & $\mathrm{R}$ & Live & 60 to 80 years & Phase 3 & India & NCT04475302 \\
\hline $\begin{array}{l}\text { Safety and immunogenicity of two } \\
\text { different strengths of the inactivated } \\
\text { COVID-19 vaccine ERUCOV-VAC }\end{array}$ & $\mathrm{R}$ & Inactivated & 18 to 55 years & Phase 1 & Turkey & NCT04691947 \\
\hline $\begin{array}{l}\text { An effectiveness study of the Sinovac's } \\
\text { adsorbed COVID-19(inactivated) } \\
\text { vaccine }\end{array}$ & $\mathrm{A}, \mathrm{NR}$ & Inactivated vaccine & $\begin{array}{l}18 \text { years and } \\
\text { older }\end{array}$ & Phase 4 & Brazil & NCT04747821 \\
\hline $\begin{array}{l}\text { Efficacy of hydroxychloroquine (HCQ) } \\
\text { as post-exposure prophylaxis (PEP) } \\
\text { for prevention of COVID-19 }\end{array}$ & $\mathrm{C}$ & Drug: hydroxychloroquine & $\begin{array}{l}18 \text { years and } \\
\text { older }\end{array}$ & Phase 3 & India & NCT04408456 \\
\hline $\begin{array}{l}\text { Study on sequential immunization of } \\
\text { recombinant COVID-19 vaccine } \\
\text { (Ad5 vector) and RBD-based protein } \\
\text { subunit vaccine }\end{array}$ & $\mathrm{A}, \mathrm{NR}$ & Recombinant vaccine & $\begin{array}{l}18 \text { years and } \\
\text { older }\end{array}$ & Phase 4 & China & NCT04833101 \\
\hline $\begin{array}{l}\text { Efficacy, immunogenicity, and safety of } \\
\text { the inactivated COVID-19 vaccine } \\
\text { (TURKOVAC) versus the } \\
\text { CoronaVac vaccine }\end{array}$ & $\mathrm{R}$ & Inactivated vaccine & 18 to 55 years & Phase 3 & Turkey & NCT04942405 \\
\hline $\begin{array}{l}\text { Clinical trial to assess safety and } \\
\text { immunogenicity of }\end{array}$ & A, NR & Viral vector & $\begin{array}{l}18 \text { years and } \\
\text { older }\end{array}$ & Phase & 2/phase 3 & India \\
\hline
\end{tabular}

Gam-COVID-Vac combined vector vaccine for severe acute respiratory syndrome

Coronavirus 2 (SARS-Cov-2) infection NCT04640233

Serological response to mRNA and inactivated COVID-19 vaccine in health care workers in Hong Kong

Mix and match of the second COVID-19 vaccine dose for safety and immunogenicity

A study to evaluate MVC-COV1901 vaccine against COVID-19 in adult

Clinical trial for SARS-CoV-2 vaccine (COVID-19)

Safety and immunogenicity of the inactivated KoÃßak-19 Inaktif Adjuvan $1 \ddot{A} \pm$ COVID-19 vaccine compared to placebo

COVID-19 vaccination of immunodeficient persons (COVAXID)

Clinical trial to evaluate the efficacy, immunogenicity, and safety of the inactivated SARS-CoV-2 vaccine (COVID-19)

A study to assess the safety and immunogenicity of the corona vaccine against COVID-19

Safety and immunity of COVID-19 APC vaccine

A clinical trial to evaluate the recombinant SARS-CoV-2 vaccine (CHO Cell) for COVID-19

\author{
$\mathrm{R} \quad$ Inactivated vaccine \\ R mRNA vaccine \\ A, NR S protein with adjuvant \\ $\mathrm{R} \quad$ Inactivated \\ R Adjuvant \\ $\mathrm{R} \quad$ mRNA vaccine \\ A, NR Inactivated vaccine
}

A, NR Inactivated vaccine

R Pathogen-specific APC

R Recombinant vaccine
18 years and older

18 to 99 years

20 and older

18 to 59 years

18 to 55 years

Phase

Phase

18 and older

Phase

18 to 85 years

Phase

18 years and older Â

(adult, older

adult)

6 months to 80 years

3 years and older Â (child, adult, older
Hong Kong

NCT04898946

NCT04894435

NCT04695652

NCT04582344

NCT04838080

Turkey

Sweden

NCT04780659

NCT04560881

Argentina

Phase 4 Brazil

NCT04756830

China

NCT04299724

1/phase 2 China 
Table 2 (continued)

\begin{tabular}{|c|c|c|c|c|c|c|}
\hline Title & Status & Interventions & Age & Phases & Locations & NCT number \\
\hline & & & adult) & & & \\
\hline \multicolumn{7}{|l|}{ NCT04869592 } \\
\hline $\begin{array}{l}\text { Clinical trial of efficacy and safety of } \\
\text { Sinovac's adsorbed } \\
\text { COVID-19(inactivated) vaccine in } \\
\text { healthcare professionals }\end{array}$ & A, NR & Inactivated vaccine & $\begin{array}{l}18 \text { years and } \\
\text { older }\end{array}$ & Phase 3 & Brazil & NCT04456595 \\
\hline $\begin{array}{l}\text { A study to evaluate the efficacy, safety, } \\
\text { and immunogenicity of inactivated } \\
\text { SARS-CoV-2 vaccines (vero cell) in } \\
\text { a healthy population aged } 18 \text { years } \\
\text { old and above }\end{array}$ & $\mathrm{R}$ & Inactivated vaccine & $\begin{array}{l}18 \text { years and } \\
\text { older }\end{array}$ & Phase 3 & $\begin{array}{c}\text { United Arab } \\
\text { Emirates }\end{array}$ & NCT04510207 \\
\hline $\begin{array}{l}\text { The phase I clinical trial of booster } \\
\text { vaccination of adenovirus type- } 5 \\
\text { vectored COVID-19 vaccine }\end{array}$ & A, NR & Viral vector & $\begin{array}{l}\text { Child, adult, } \\
\text { older adult }\end{array}$ & Phase 1 & China & NCT04568811 \\
\hline $\begin{array}{l}\text { Study on sequential immunization of } \\
\text { inactivated SARS-CoV-2 vaccine } \\
\text { and recombinant SARS-CoV-2 vac- } \\
\text { cine (Ad5 vector) }\end{array}$ & A, NR & Recombinant vaccine & 18 to 59 years & Phase 4 & China & NCT04892459 \\
\hline $\begin{array}{l}\text { Phase I trial of a recombinant } \\
\text { COVID-19 vaccine (CHO cell) }\end{array}$ & $\mathrm{R}$ & Recombinant vaccine & $\begin{array}{l}18 \text { years and } \\
\text { older }\end{array}$ & Phase 1 & China & NCT04636333 \\
\hline $\begin{array}{l}\text { Efficacy, safety, and immunogenicity of } \\
\text { inactivated SARS-CoV-2 vaccines }\end{array}$ & A, NR & Inactivated & $\begin{array}{l}18 \text { years and } \\
\text { older }\end{array}$ & Phase 3 & Peru & NCT04612972 \\
\hline
\end{tabular}
(vero cell) to prevent COVID-19 in a healthy adult population in Peru healthy adult population in Peru

A study of SARS-CoV-2 infection and $\mathrm{R}$ mRNA-based vaccine

18 to 29 years Phase 3 USA

NCT04811664 potential transmission in individuals immunized with Moderna COVID-19 vaccine

An immuno-bridging and immunization $\mathrm{R} \quad$ Inactivated schedules study of COVID-19 vaccine (vero cell), inactivated

Hydroxychloroquine (HCQ) as post-exposure prophylaxis (PEP) for prevention of COVID-19

Phase â...£ clinical trial of inactivated $\mathrm{R} \quad$ Inactivated vaccine SARS-CoV-2 vaccine for prevention of COVID-19 in healthy adults

Profiling antibody status and vaccine effectiveness in post-vaccination with SARS CoV2 in Ain Shams University

NCT04885764

Clinical trial of efficacy, safety, and immunogenicity of Gam-COVID-Vac vaccine against COVID-19 in Belarus

COVAXIN in a pediatric cohort

18 to 60 years

Safety and immunogenicity study of inactivated vaccine for prevention of SARS-CoV-2 infection (COVID-19) NCT04383574

Impact of the immune system on response to anti-coronavirus disease 19 (COVID-19) vaccine in allogeneic stem cell recipients (COVID VaccinAllo)
R Drug: hydroxychloroquine (HCQ)

R Viral vector

A, NR Viral vector

Phase 3

Belarus

NCT04564716

\begin{tabular}{|c|c|c|}
\hline $\begin{array}{l}3 \text { years and } \\
\text { older }\end{array}$ & Phase 4 & China \\
\hline 18 years and & Phase 3 & India \\
\hline
\end{tabular}

18 to 59 years Phase 4 Beijing, China

18 years and Phase older

2 to 18 years

Phase

2/phase 3

India

$\mathrm{NC}-$

T04918797
A, NR Inactivated vaccine
60 and older
Phase
1/phase 2
China

$\mathrm{R}$ mRNA-based vaccine
18 to 100 years

NCT04951323 
Table 2 (continued)

\begin{tabular}{|c|c|c|c|c|c|c|}
\hline Title & Status & Interventions & Age & Phases & Locations & NCT number \\
\hline $\begin{array}{l}\text { Efficacy of hydroxychloroquine (HCQ) } \\
\text { as post-exposure prophylaxis (PEP) } \\
\text { for prevention of COVID-19 }\end{array}$ & & & $\begin{array}{l}18 \text { years and } \\
\text { older }\end{array}$ & & & \\
\hline $\begin{array}{l}\text { A study on the safety, tolerability, and } \\
\text { immune response of SARS-CoV-2 } \\
\text { Sclamp (COVID-19) vaccine in } \\
\text { healthy Adults }\end{array}$ & $\mathrm{R}$ & Adjuvant & $\begin{array}{l}18 \text { years and } \\
\text { older }\end{array}$ & Phase 1 & Australia & NCT04495933 \\
\hline $\begin{array}{l}\text { Efficacy, immunogenicity, and safety of } \\
\text { inactivated ERUCOV-VAC com- } \\
\text { pared with placebo in COVID-19 }\end{array}$ & $\mathrm{R}$ & Inactivated vaccine & 18 to 64 years & Phase 2 & Turkey & NCT04824391 \\
\hline $\begin{array}{l}\text { Clinical trial of efficacy, safety, and } \\
\text { immunogenicity of } \\
\text { Gam-COVID-Vac vaccine against } \\
\text { COVID-19 }\end{array}$ & A, NR & Viral vector & $\begin{array}{l}18 \text { to } 111 \\
\text { years }\end{array}$ & Phase 3 & $\begin{array}{r}\text { Moscow, } \\
\text { Russia }\end{array}$ & NCT04530396 \\
\hline $\begin{array}{l}\text { Safety and efficacy of a non-replicating } \\
\text { ChAdOx1 vector vaccine AZD1222 } \\
\text { (COVISHIELD) for prevention of } \\
\text { COVID-19 in patients with liver cir- } \\
\text { rhosis }\end{array}$ & $\mathrm{R}$ & Recombinant & $\begin{array}{l}18 \text { years and } \\
\text { older }\end{array}$ & $\begin{array}{l}\text { Not } \\
\text { appli- } \\
\text { cable }\end{array}$ & India & NCT04794946 \\
\hline $\begin{array}{l}\text { Lot-to-lot consistency of an inactivated } \\
\text { SARS-CoV-2 vaccine for prevention } \\
\text { of COVID-19 in healthy adults }\end{array}$ & $\mathrm{A}, \mathrm{NR}$ & Inactivated & 26 to 45 years & Phase 4 & China & NCT04894227 \\
\hline $\begin{array}{l}\text { Study to evaluate the immunogenicity } \\
\text { and safety of heterologous } \\
\text { SARS-CoV-2 vaccine schemes }\end{array}$ & $\mathrm{R}$ & $\begin{array}{l}\text { Drug: } \\
\text { Gam-COVID-Vac/Gam-COVID-- } \\
\text { Vac }\end{array}$ & 21 to 65 years & Phase 2 & Argentina & NCT04962906 \\
\hline $\begin{array}{l}\text { Safety and immunogenicity study of } \\
2019 \text {-nCoV vaccine (mRNA-1273) } \\
\text { for prophylaxis of SARS-CoV-2 in- } \\
\text { fection (COVID-19) }\end{array}$ & A, NR & mRNA vaccine & 18 to 99 years & Phase 1 & $\begin{array}{l}\text { Washington, } \\
\text { USA }\end{array}$ & NCT04283461 \\
\hline $\begin{array}{l}\text { Study of monovalent and bivalent } \\
\text { recombinant protein vaccines against } \\
\text { COVID-19 in adults } 18 \text { years of age } \\
\text { and older }\end{array}$ & $\mathrm{R}$ & $\begin{array}{l}\text { Adjuvanted recombinant protein } \\
\text { vaccine }\end{array}$ & $\begin{array}{l}18 \text { years and } \\
\text { older }\end{array}$ & Phase 3 & Japan & NCT04904549 \\
\hline $\begin{array}{l}\text { Safety and immunogenicity of an } \\
\text { intranasal SARS-CoV-2 vaccine } \\
\text { (BBV154) for COVID-19 }\end{array}$ & $\mathrm{A}, \mathrm{NR}$ & Viral vector & 18 to 60 years & Phase 1 & India & NCT04751682 \\
\hline $\begin{array}{l}\text { Phase I clinical trial of a COVID-19 } \\
\text { vaccine in } 18-60 \text { healthy adults }\end{array}$ & $\mathrm{A}, \mathrm{NR}$ & Recombinant vaccine & 18 to 60 years & Phase 1 & China & NCT04313127 \\
\hline $\begin{array}{l}\text { Third dose of Moderna COVID-19 } \\
\text { vaccine in transplant recipients }\end{array}$ & $\mathrm{A}, \mathrm{NR}$ & mRNA vaccine & $\begin{array}{l}18 \text { years and } \\
\text { older }\end{array}$ & Phase 4 & Canada & NCT04885907 \\
\hline $\begin{array}{l}\text { Safety, tolerability, and } \\
\text { immunogenicity of the COVID-19 } \\
\text { vaccine candidate (VBI-2902a) } \\
\text { NCT04773665 }\end{array}$ & $\mathrm{A}, \mathrm{NR}$ & Virus-like particle & $\begin{array}{l}18 \text { years and } \\
\text { older }\end{array}$ & Phase & $1 /$ phase 2 & Canada \\
\hline $\begin{array}{l}\text { Polio vaccine (IPV) for SARS-CoV-2 } \\
\text { and prevention of coronavirus dis- } \\
\text { ease (COVID-19) }\end{array}$ & $\mathrm{R}$ & Polio vaccine & 18 to 80 years & Phase 4 & USA & NCT04639375 \\
\hline
\end{tabular}


lesser side effects. This concept can produce a health care approach and also as a placebo effect. The social life of the people can be improved and also the mental health.

This economical, safe, user-friendly combination strategy can be used by all individuals as a health care regime and also as a placebo effect. This combination can help in improving the social life of the people and improved focus on the workplace, which helps in improving the country's economy.

The parent component used in this formulation is easily accessible and economical. Since the input is economical, the output is also economical and it can be easily accessed too.

The herbal or natural products are environment-friendly and accessible. The waste material and by-products are biodegradable and environment-friendly. The main concept behind is the mother nature that has provided the remedy for all the disease and ailments what the living things face (Karthika and Sureshkumar 2021). The other natural regimen used for the treatment of depression is given in Table 3.

\section{Current aspects and future perspective}

Several sensitive measures should be proposed to control COVID-19 transmission in the population. The first and most important strategy is to limit personal contact and maintain personal hygiene. The governments of various countries had taken a variety of preventive measures to halt the virus' global spread. Special precautions should be taken to prevent disease spread and transmission to vulnerable populations such as pediatrics, geriatrics, and health care professionals. The government is introducing various schemes and funding to entice researchers to work in the COVID-19 field (Zhu et al. 2020, Ngandu et al. 2015, Wang et al. 2020a, b, c, Toots et al. 2019). When physical contact is made with contaminated and wet objects, such as urine and fecal matters, which are thought to effectively deal with the virus, an alternative route of transmission of this disorder is established. As a result, physicians and other healthcare workers should wash their hands regularly. According to various reports, health care workers and their families are also becoming infected with this virus. According to reports, coronavirus cases are seen twice or three times in the same person. Almost every country has implemented travel screening as a control and preventive measure to prevent the virus from spreading further on a global scale; in the meantime, they have imposed restrictions on airway transport (Cui et al. 2019; Ngandu et al. 2015).

The high mortality rate in the population is primarily due to patients weakened immune systems. On the other hand, the patient's recovery rates must also be taken into account. Approaches or remedies are used to boost an individual's

Table 3 Natural remedies used for the treatment of depression

\begin{tabular}{|c|c|c|c|}
\hline $\begin{array}{l}\text { SL. } \\
\text { no }\end{array}$ & Natural remedies & Short presentation & References \\
\hline 1 & $\begin{array}{l}\text { Wu Wei: principle of } \\
\text { non-resistance }\end{array}$ & $\begin{array}{l}\text { Let the things happen in their way, accept. If there is a storm, let it roar; one day, it will calm } \\
\text { down by itself. This is a Taoist saying, before } 2500 \text { years ago by a Chinese Philosopher. }\end{array}$ & Chen et al. 2016 \\
\hline 2 & Lavender & $\begin{array}{l}\text { Blue-violet inflorescence acts as a relaxant, useful as an anti-depressant. Infusions can be } \\
\text { used for internal and external use. Tea with lavender helps to calm down, act as anger } \\
\text { soothe, aid relaxation and is useful with depression and insomnia. }\end{array}$ & Kianpour et al. 2016 \\
\hline 3 & $\begin{array}{l}\text { Aerobic exercise against } \\
\text { depression }\end{array}$ & $\begin{array}{l}\text { Reports suggest that walking and exercise can reduce depression. But in this pandemic, } \\
\text { walking outside is not considered to be safe; hence, doing exercise and practicing Yoga } \\
\text { indoor safely is advisable. }\end{array}$ & Herbert et al. 2020 \\
\hline 4 & $\begin{array}{l}\text { Chromotherapy, the power } \\
\text { to heal with colors }\end{array}$ & $\begin{array}{l}\text { Chromotherapy is mainly based on the idea that colors can have a positive impact on our } \\
\text { health and our mood. There is the hypothetic report that colors can produce an } \\
\text { electromagnetic wave which indeed can help with the synthesis of hormones such as } \\
\text { melatonin and serotonin. A room with white lights than dim lights can help inward off } \\
\text { depression. }\end{array}$ & Chappaz et al. 2017 \\
\hline 5 & Osmanthus essential oil & $\begin{array}{l}\text { Osmanthus fragrance can produce an anxiolytic effect with its sedative and calming action } \\
\text { and can be used as diffusion in rooms with an oil burner. }\end{array}$ & Pai et al. 2020 \\
\hline 6 & Vitamin D & $\begin{array}{l}\text { Vitamin D can improve mood, will support the immune system, and can improve brain } \\
\text { function. The potent candidate as an anti-depressant and in COVID treatment. }\end{array}$ & $\begin{array}{l}\text { Menon et al. 2020, } \\
\text { Mitchell } 2020\end{array}$ \\
\hline 7 & Hyssop & $\begin{array}{l}\text { Hyssop plant can be used in the cases of bronchitis or cough condition, as an expectorant; in } \\
\text { addition, it has an anti-inflammatory property and as anti-depressants. It can be used for } \\
\text { the management and mitigation of depression and against the coronavirus. }\end{array}$ & Irshad et al. 2020 \\
\hline 8 & Clove essential oil & An anti-viral and anti-depressant combination is effective during this COVID-19 situation. & Hussain et al. 2017 \\
\hline 9 & Angelica essential oil & $\begin{array}{l}\text { With its antispasmodic, anti-inflammatory, and anti-depressant effect, it revitalizes itself } \\
\text { during the COVID crisis. }\end{array}$ & Zhou et al. 2020 \\
\hline 10 & YlangYlang essential oil & $\begin{array}{l}\text { Its relaxing and calming action is helpful during insomnia, irritability, anxiety, and } \\
\text { depression conditions. }\end{array}$ & $\begin{array}{l}\text { Rezaie-Keikhaie } \\
\text { et al. } 2019\end{array}$ \\
\hline
\end{tabular}


immune system. One such method is to drink lemon water. The lemon is regarded as a natural immune booster and can serve as a preventive measure against this viral attack to some extent. Another measure is to gargle with hot water, which can wash out the virus in the throat and prevent its growth and multiplication. However, it is unclear how far these remedies will go. In addition, to the evolution, adaptation, and spread of the disease, the major challenges that should be effectively monitored are epidemiological changes and mutation. It has also been reported that the disease has spread to pet animals such as dogs (Cui et al. 2019; Bassetti et al. 2020). Other questions about this pandemic situation remain unanswered. Despite this, there is a belief that mother nature has a cure for all diseases and pain in humans and animals. Will she also have a cure for this pandemic situation? The mother is healing herself, which is good news during this situation.

\section{Conclusion}

COVID-19 is a condition that must be investigated and carefully considered. There is a strong push for the development of novel formulations or drug development to combat the infection's attack. Vaccines and new drugs require time to be developed in order to pass quality, safety, and efficacy tests. As a result, it is advised to rely on herbal remedies that are considered safe and can be used as an effective tool for the management of this infection. Nature has endowed us with a tremendous inherent ability to combat pandemic issues such as COVID-19. A combination strategy could be an effective method to use. The combination of the two drugs can be two herbals such as flavonoids or a chemical moiety and herbal remedy, but the compatibility studies should come first. One such example is the use of quercetin in conjunction with a prophylactic agent to produce a synergistic effect. Quercetin has the ability to inhibit hemagglutinin-esterase, which is found in the virus structure. Curcumin is also an effective agent with anti-viral and anti-inflammatory properties. The use of volatile anti-viral agents can also aid in the treatment of corona viral infection to some extent. Because the lungs and upper respiratory tract are the primary organs affected by this infection, the volatile nature of the drugs can be useful in the management and prevention of this infection. To some extent, selecting the appropriate delivery or formulation could also help. The use of nanoparticles in the treatment of pulmonary infections is well documented. The surfactants used in the formulation of the nanoparticles aid in reducing the interfacial tension between cells and even the alveoli, making drug delivery much more beneficial when using nanotechnology. Several vaccines have been developed, and others are in different phases of clinical trials, but still, any treatment options were not developed which can completely prevent the
COVID-19 infection. Hence, further research will continue to make successful treatment options to eradicate this virus.

Acknowledgements All authors thanks to the Department of Pharmaceutics, JSS College of Pharmacy, Ooty, India, and the Department of Pharmacy, Southeast University, Banani, 1213, Dhaka, Bangladesh, for support for this study.

Author contribution Chenmala Karthika - concept behind the article and review; Swathy Krishna R - literature survey; Md. Habibur Rahman editing; Rokeya Akter and Deepak Kaushik - literature survey and editing. All the authors had read the manuscript and approved for submission.

Data availability Not applicable

\section{Declarations}

Ethics approval and consent to participate Not applicable

Consent for publication Not applicable

Competing interests Not applicable

Author information Not applicable

Scientific and ethical concern Not applicable

\section{References}

Andrade BS, Siqueira S, Soares WR d A, Rangel F d S, Santos NO, Freitas A d S, Silveira PR d, Tiwari S, Alzahrani KJ, Góes-Neto A, Azevedo V, Ghosh P, Barh D (2021)Long-COVID and postCOVID health complications: an up-to-date review on clinical conditions and their possible molecular mechanisms. Viruses 13(4):700. https://doi.org/10.3390/V13040700

Assiri A, Al-Tawfiq JA, Al-Rabeeah AA, Al-Rabiah FA, Al-Hajjar S, AlBarrak A, Flemban H, Al-Nassir WN, Balkhy HH, Al-Hakeem RF, Makhdoom HQ (2013a) Epidemiological, demographic, and clinical characteristics of 47 cases of Middle East respiratory syndrome coronavirus disease from Saudi Arabia: a descriptive study. Lancet Infect Dis 13(9):752-761

Assiri A, McGeer A, Perl TM, Price CS, Al Rabeeah AA, Cummings DA, Alabdullatif ZN, Assad M, Almulhim A, Makhdoom H, Madani H (2013b) Hospital outbreak of Middle East respiratory syndrome coronavirus. New England J of Med 369(5):407-416

Bassetti M, Vena A, Giacobbe DR (2020) The novel Chinese coronavirus (2019-nCoV) infections: challenges for fighting the storm Eur. J Clin Invest 50(3):e13209

Bogoch II, Watts A, Thomas-Bachli A, Huber C, Kraemer MU, Khan K (2020) Pneumonia of unknown etiology in Wuhan, China: potential for international spread via commercial air travel. J Travel Med 27(2):taaa008. https://doi.org/10.1093/jtm/taaa008

Brubaker MD, Amatea EA, Torres-Rivera E, Miller MD, Nabors L (2013) Barriers and supports to substance abuse service use among homeless adults. J Addict Offender Couns 34(2):81-98

Calisher C, Carroll D, Colwell R, Corley RB, Daszak P, Drosten C, Enjuanes L, Farrar J, Field H, Golding J, Gorbalenya A (2020) Statement in support of the scientists, public health professionals, 
and medical professionals of China combatting COVID-19. Lancet 395(10226):e42-e43

Chappaz C, Gall A, Nuzzo C, Billonnet L (2017) A 4-In-1 Chromotherapy, Aromatherapy, light therapy, music therapy product for well-being of people. Telemed. J. E Health 5:GKR-e20.

Chen JZ, Ji Y, Fo L, Fusing Western and Daoist Poetics (2016) In Canadian-Daoist poetics, ethics, and aesthetics Springer. Berlin, Heidelberg:49-72

Corman VM, Landt O, Kaiser M, Molenkamp R, Meijer A, Chu DK, Bleicker T, Brünink S, Schneider J, Schmidt ML, Mulders DG (2020) Detection of 2019 novel coronavirus (2019-nCoV) by realtime RT-PCR. Euro Surveill 25(3)

Cui J, Li F, Shi ZL (2019) Origin and evolution of pathogenic coronaviruses. Nat Rev Microbiol 17(3):181-192

Dou J, Chen L, Xu G, Zhang L, Zhou H, Wang H, Su Z, Ke M, Guo Q, Zhou C (2011) Effects of baicalein on Sendai virus in vivo are linked to serum baicalin and its inhibition of hemagglutininneuraminidase. Arch Virol 156(5):793-801

Du Toit A (2020) Outbreak of a novel coronavirus. Nat Rev Microbiol 18(3):123

Fehr AR, Perlman S (2015) Coronaviruses: an overview of their replication and pathogenesis. Mol Biol 2015 1282:1-23. https://doi.org/10. 1007/978-1-4939-2438-7_1

Herbert C, Meixner F, Wiebking C, Gilg V (2020) Regular physical activity, short-term exercise, mental health, and well-being among university students: the results of an online and a laboratory study. Front Psychol 11:509

Holshue MLD, Lindquist SL, Wiesman JB, Spitters CE, Wilkerson ST (2020) First case of 2019 novel corona virus in the United States. NEngl J Med 2020:929-936. https://doi.org/10.1056/ NEJMoa2001191

Huang J, Tao G, Liu J, Cai J, Huang Z, Chen J (2020) Current prevention of COVID-19: natural products and herbal medicine. Front Pharmacol 11:1635. https://doi.org/10.3389/FPHAR.2020.588508

Hui DS, Azhar IE, Madani TA, Ntoumi F, Kock R, Dar O, Ippolito G, Mchugh TD, Memish ZA, Drosten C, Zumla A (2020) The continuing 2019-nCoV epidemic threat of novel coronaviruses to global health - the latest 2019 novel coronavirus outbreak in Wuhan, China. Int J Infect Dis 91:264-266

Hossain MF, Hasana S, Al Mamun A, Uddin MS, Wahed MI, Sarker S, Behl T, Ullah I, Begum Y, Bulbul IJ, Amran MS (2020)COVID-19 outbreak: pathogenesis, current therapies, and potentials for future management. Front Pharmacol 11

Hussain S, Rahman R, Mushtaq A, Belaskri AE (2017) Clove: a review of a precious species with multiple uses. Int J Boil Chem 11:129133

Irshad M, Subhani MA, Ali S, Hussain A (2020) Biological importance of essential oils. Essential Oils-Oils of Nature

Jaimes JA, Millet JK, Stout AE, André NM, Whittaker GR (2020) A tale of two viruses: the distinct spike glycoproteins of feline coronaviruses. Viruses 12(1):83

Jin YH, Cai L, Cheng ZS, Cheng H, Deng T, Fan YP, Fang C, Huang D, Huang LQ, Huang Q, Han Y (2020) A rapid advice guideline for the diagnosis and treatment of 2019 novel coronavirus (2019-nCoV) infected pneumonia (standard version). Mil Med Res 7(1):4

Khaerunnisa S, Kurniawan H, Awaluddin R, Suhartati S, Soetjipto S (2020) Potential inhibitor of COVID-19 main protease (Mpro) from several medicinal plant compounds by molecular docking study. https://doi.org/10.20944/PREPRINTS202003.0226.V1

Karthika C, Sureshkumar R (2021) Can nature heal and be a possible remedy for the management of Covid-19? Infect Disord Drug Targets 21. https://doi.org/10.2174/1871526521999210111202954

Kianpour M, Mansouri A, Mehrabi T, Asghari G (2016) Effect of lavender scent inhalation on prevention of stress, anxiety and depression in the postpartum period. Iran J Nurs Midwifery Res 21(2):197-201
Lalani S, Poh CL (2020) Flavonoids as antiviral agents for Enterovirus A71 (EV-A71). Viruses 12(2):184

Lee N, Hui D, Wu A, Chan P, Cameron P, Joynt GM, Ahuja A, Yung MY, Leung CB, To KF, Lui SF (2003) A major outbreak of severe acute respiratory syndrome in Hong Kong. N Engl J Med 348(20): 1986-1994

Lu H, Stratton CW, Tang YW (2020a) Outbreak of pneumonia of unknown etiology in Wuhan China: the mystery and the miracle. J Med Virol 92(4):401-402. https://doi.org/10.1002/jmv.25678

Lu R, Zhao X, Li J, Niu P, Yang B, Wu H, Wang W, Song H, Huang B, Zhu N, Bi Y (2020b) Genomic characterisation and epidemiology of 2019 novel coronavirus: implications for virus origins and receptor binding. Lancet 395(10224):565-574

Menon V, Kar SK, Suthar N, Nebhinani N (2020) Vitamin D and depression: a critical appraisal of the evidence and future directions. Indian J Psychol Med 42(1):11-21

Mitchell F. Vitamin-D and COVID-19: do deficient risk a poorer outcome? (2020) The Lancet Diabetes \& Endocrinology 8(7):570.

Moniruzzaman M, Hossain MU, Islam MN, Rahman MH, Ahmed I, Rahman TA, Bhattacharjee A, Amin MR, Rashed A, Keya CA, Das KC (2020)Coding-complete genome sequence of SARSCoV-2 isolate from Bangladesh by sanger sequencing. Microbiology Resource Announcements 9(28):e00626-e00620

Ngandu T, Lehtisalo J, Solomon A, Levälahti E, Ahtiluoto S, Antikainen R, Bäckman L, Hänninen T, Jula A, Laatikainen T, Lindström J (2015) A 2year multidomain intervention of diet, exercise, cognitive training, and vascular risk monitoring versus control to prevent cognitive decline in at-risk elderly people (FINGER): a randomised controlled trial. Lancet 385(9984):2255-2263

Nishiura H, Jung SM, Linton NM, Kinoshita R, Yang Y, Hayashi K, Kobayashi T, Yuan B, Akhmetzhanov AR (2020) The extent of transmission of novel coronavirus in Wuhan, China. J Clin Med 9(2):330. https://doi.org/10.3390/jcm9020330

Pablos J, Abasolo Lydia, Alvaro-Gracia J, Blanco F J, Blanco R, castrejón isabel, Fernandez-Fernandez david, Fernandez-gutierrez $\mathrm{B}$, galindo-izquierdo, maría, gonzalez-gay, miguel, manrique-arija, sara, mena Vázquez, natalia, mera Varela, antonio, Retuerto, miriam, \& seijas-lopez, alvaro (2020) Prevalence of hospital PCRconfirmed COVID-19 cases in patients with chronic inflammatory and autoimmune rheumatic diseases. Ann Rheum Dis 0, 1-4. https:// doi.org/10.1136/annrheumdis-2020-217763, 79

Pai SR, Sonkamble VV, Wagh NS (2020) Essential oils as effective agents against neurological disorders. InPlant-derived Bioactives 2020 Springer, Singapore. 409-433.https://doi.org/10.1007/978981-15-1761-7 17

Pastor N, Collado MC, \& Manzoni P (2021) Phytonutrient and nutraceutical action against COVID-19: current review of characteristics and benefits. https://doi.org/10.3390/nu13020464

Phan LT, Nguyen TV, Luong QC, Nguyen TV, Nguyen HT, Le HQ, Nguyen TT, Cao TM, Pham QD (2020) Importation and human-tohuman transmission of a novel coronavirus in Vietnam. N Engl J Med 382(9):872-874

Rahman MH, Akter R, Behl T, Chowdhury MA, Mohammed M, Bulbul IJ, Elshenawy SE, Kamal MA (2020)COVID-19 outbreak and emerging management through pharmaceutical therapeutic strategy. Curr Pharm Des 26(41):5224-5240

Rahman MH, Zafri NM, Ashik FR, Waliullah M, Khan A (2021) Identification of risk factors contributing to COVID-19 incidence rates in Bangladesh: a GIS-based spatial modeling approach. Heliyon 7(2):e06260

Rezaie-Keikhaie K, Hastings-Tolsma M, Bouya S, Shad FS, Sari M, Shoorvazi M, Barani ZY, Balouchi A (2019) Effect of aromatherapy on post-partum complications: a systematic review. Complement Ther Clin Pract 35:290-295 
Rothan HA, Byrareddy SN (2020) The epidemiology and pathogenesis of coronavirus disease (COVID-19) outbreak. J Autoimmun 109: 102433. https://doi.org/10.1016/j.jaut.2020.102433

Setorki M (2020) Medicinal herbs with anti-depressant effects. J Herbmed Pharmacol 9(4):309-317

Shah SA, Bungau S, Si Y, Xu H, Rahman M, Behl T, Gitea D, Pavel FM, Corb Aron RA, Pasca B, Nemeth S (2021) Chemically diverse and biologically active secondary metabolites from marine Phylum chlorophyta. Marine Drugs 18(10):493

Sharma S, Batra S, Gupta S, Sharma VK, Rahman MH, Kamal MA (2021) Persons with co-existing neurological disorders: risk analysis, considerations and management in COVID-19 pandemic. CNS Neurol Disord Drug Targets 20

Thompson R (2020) Pandemic potential of 2019-nCoV. Lancet Infect Dis 20(3):280

Toots M, Yoon JJ, Cox RM, Hart M, Sticher ZM, Makhsous N, Plesker R, Barrena AH, Reddy PG, Mitchell DG, Shean RC (2019) Characterization of orally efficacious influenza drug with high resistance barrier in ferrets and human airway epithelia. Sci Transl Med 11(515):eaax5866

Törnblom H, Drossman DA (2018) Psychotropics, antidepressants, and visceral analgesics in functional gastrointestinal disorders. Curr Gastroenterol Rep 20(12):1-0.

UPDATED Comparing COVID-19 vaccines: timelines, types and prices | BioSpace. (n.d.). Retrieved July 21, 2021, from https://www. biospace.com/article/comparing-covid-19-vaccines-pfizerbiontech-moderna-AstraZeneca-oxford-j-and-j-russia-s-sputnik-v/

Van Hees S, Fodjo JN, Wijtvliet V, Van den Bergh R, de MouraVillela EF, da Silva CF, Weckhuysen S, Colebunders R (2020) Access to healthcare and prevalence of anxiety and depression in persons with epilepsy during the COVID-19 pandemic: a multicountry online survey. Epilepsy Behav 112:107350

Wan Y, Shang J, Graham R, Baric RS, Li F (2020) Receptor recognition by the novel coronavirus from Wuhan: an analysis based on decadelong structural studies of SARS coronavirus. J Virol 94(7)

Wang M, Cao R, Zhang L, Yang X, Liu J, Xu M, Shi Z, Hu Z, Zhong W, Xiao G (2020a) Remdesivir and chloroquine effectively inhibit the recently emerged novel coronavirus $(2019-\mathrm{nCoV})$ in vitro. Cell Res 30(3):269-271
Wang W, Tang J, Wei F (2020b) Updated understanding of the outbreak of 2019 novel coronavirus (2019-nCoV) in Wuhan, China. J Med Virol 92(4):441-447

Wang Z, Chen X, Lu Y, Chen F, Zhang W (2020c) Clinical characteristics and therapeutic procedure for four cases with 2019 novel coronavirus pneumonia receiving combined Chinese and Western medicine treatment. Biosci Trends 14:64-68. https://doi.org/10.5582/ bst. 2020.01030

What you need to know about COVID-19 vaccines | UNICEF. (n.d.). Retrieved July 21, 2021, from https://www.unicef.org/coronavirus/ what-you-need-to-know-covid-vaccine

Woods HC, Scott H (2016) Sleepyteens: Social media use in adolescence is associated with poor sleep quality, anxiety, depression and low self-esteem. J Adolesc 51:41-49

Wu P, Hao X, Lau EH, Wong JY, Leung KS, Wu JT, Cowling BJ, Leung GM (2020)Real-time tentative assessment of the epidemiological characteristics of novel coronavirus infections in Wuhan, China, as at 22 January 2020. Euro Surveill 25(3)

Zakaryan H, Arabyan E, Oo A, Zandi K (2017) Flavonoids: promising natural compounds against viral infections. Arch Virol 162(9): 2539-2551

Zhao S, Lin Q, Ran J, Musa SS, Yang G, Wang W, Lou Y, Gao D, Yang L, He D, Wang MH (2020) Preliminary estimation of the basic reproduction number of novel coronavirus (2019-nCoV) in China, from 2019 to 2020: a data-driven analysis in the early phase of the outbreak. Int J Infect Dis 92:214-217

Zhou Y, Miao X, Lan X, Luo J, Luo T, Zhong Z, Gao X, Mafang Z, Ji J, Wang H, Tang Y (2020) angelica essential oil loaded electrospun gelatin nanofibers for active food packaging application. Polymers 12(2):299.

Zhu N, Zhang D, Wang W, Li X, Yang B, Song J, Zhao X, Huang B, Shi W, Lu R, Niu P (2020) China novel coronavirus investigating and research team. A novel coronavirus from patients with pneumonia in China, 2019. N Engl J Med 382(8):727-733

Publisher's note Springer Nature remains neutral with regard to jurisdictional claims in published maps and institutional affiliations. 